\title{
Groundwater depletion scenario in the north-eastern and south eastern part of Bangladesh
}

\author{
Md. Juel Rana Kutub \\ Department of Geography. Faujdarhat Cadet College, Chittagong, Bangladesh \\ Email:juelrana63@yahoo.com
}

\begin{abstract}
Groundwater is one of the most important freshwater sources in Bangladesh which is used for drinking, household chores and irrigation. Due to high population pressure and excessive withdrawal, this important resource is under a lot of pressure. This study is designed to assess the present groundwater condition of the entire eastern region of Bangladesh. Groundwater depth data of 271 wells from 21 districts were collected from Bangladesh Water Development Board (BWDB) and analyzed in ArcGIS and Microsoft Excel software. During the pre-monsoon period, the groundwater lies beneath 2 to 14 meters of sediment. In the dry season, the groundwater remains between 4 and 12 meters in the northeastern part of Bangladesh. The larger values are mostly associated with urban areas. In case of southeastern part, groundwater level ranges from 2 to 8 meters. But the urbanized areas have groundwater levels in ranges in between 6 and 12. Compared to northern part, groundwater is found closer to surface in the southern part of the study area, Comilla, Mymensingh and Kishorganj. During monsoon season, there is a wide disparity of groundwater condition in the northeastern part, but southeaster part shows homogeneity. So, significant variation in groundwater depth (seasonal as well as spatial) is seen throughout the study area. The impact of urbanization is seen clearly which leads to lowering of groundwater level that can cause catastrophic events like earthquake, subsidence and pollution.
\end{abstract}

Keywords: Groundwater, regional groundwater scenario, water resource of Bangladesh

Received: April 14, 2015

Revision accepted: June 10, 2015

\section{INTRODUCTION}

Water resource is a pre-required conditions for the economic and social development of any country. Water resource, especially groundwater works as a feeder for the domestic, agriculture, industry, municipality and waste disposal use (Nwankwoala 2011). Groundwater is an important part of the hydrologic cycle, although it lies beneath the surface, beyond the soil moisture root zone. It is the largest potential freshwater source in the hydrological cycle-larger than all surface lakes and streams combined. It is estimated that $83,40,000$ cubic $\mathrm{km}$ of water is present beneath the surface of the Earth. In Bangladesh it is the single most important fresh water source for urban areas. Groundwater is not an independent source of water. It interacts with the surface water through the various mechanisms and receives from and contributes to other freshwater sources. Groundwater plays a vital role for hydraulic power and energy production, but these productions have decreased from $70 \%$ to $40 \%$ in 2004 (Oyebande 2004).Groundwater is widely used in the minimum level of technological and energy availability, because of its high quality (Shah, 1993). Groundwater is more attractive to the consumers for its more comparative per unit volume value than surface water and its local availability, reliability to drought and required minimum treatment (UN/WWAP 2003). Groundwater is considered as a vital resource for developing countries, because of the prime source for irrigation, industrial use and domestic uses (Hoque et al. 2007). Groundwater resource development and management is related to population growth, which has a significant impact on the changing depth of groundwater level (Oteze 2006).

The favorable hydrological and geological conditions in a tropical monsoonal climate of Bangladesh indicate high potential groundwater storage. Most of unconsolidated near surface and estuarine sediment from Pleistocene to recent alluvial land of Bangladesh form prolific aquifers, which indicate the high reserve of groundwater level (Zahid and Ahmed 2013). The aquifer productivity depends on the lithological characteristics of soil, where soil porosity is significant. This unconsolidated sediment can reserve a large volume of groundwater and which pumps for agriculture as well as fulfilling the demand of huge population (UNEP, 2003). The groundwater levels in shallow aquifers of Ganges Brahmaputra_Meghna (GBM) are dynamic and characterized by monsoonal rainfall (Shamsudduha et al. 2009). This shallow aquifer's depth is less than 80 meters (Klump et al. 2006). The seasonal variation of groundwater level in GangeBrahmaputra-Meghna (GBM) areas is very considerable both in temporal and spatial scales and which is ranged from 2 to 8 meters (BGS and DPHE 2001).

Bangladesh is a small country of 147570 square kilometers and huge population of about 142 million, according to a 2011 population census report (Alam 2012). Agriculture is the primary occupation of the people. Agriculture was entirely dependent on surface water and monsoonal rainfall during the 
1970s (UNDP 1982), but now 79.1\% of cultivated land are supplied groundwater through irrigation (BADC 2010, Ali 2011). Urban areas of Bangladesh are facing huge water crisis during the dry season and groundwater table of those areas are rapidly decreasing. The quality of groundwater in Bangladesh which a prime source of supplying water to most of the cities is also deteriorated, due to the pollution of groundwater by sewage and excessive exploitation of groundwater (Sengupta et al.
2012). The North-Eastern and South Eastern part of Bangladesh is mostly occupied by hilly and coastal floodplain areas, which formed by unconsolidated tertiary and Pleistocene sediments derived from tertiary rock and soil is reddish to brownish color (Rashid 1991). The coastal areas are characterized by salinity and an active floodplain which flooded regularly by high tide (Rashid and Pramanik 1990). Sylhet area is also characterized by Haor and Beel areas.

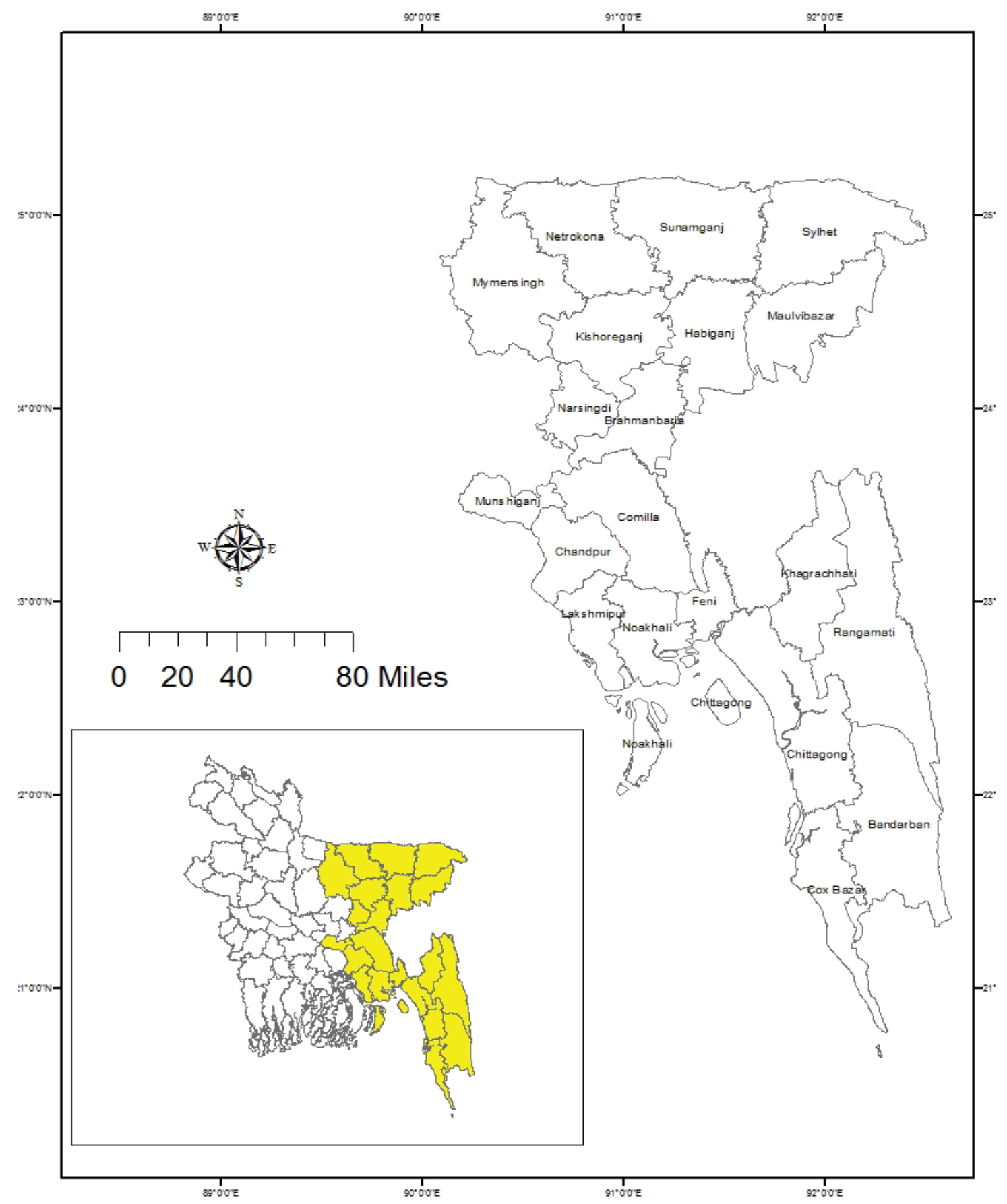

Fig. 1: Location of study area. 


\section{MATERIALS AND METHODS}

The goal of this assignment is to gain knowledge on the groundwater depth status of a selected region of Bangladesh and compare the present condition with previous data. A total of 21 districts from the northeastern, southeastern and central part of the country are selected as the study area. The study area comprises diverse physiography. Sylhet, Moulavibazar, Sunamganj, Netrokona etc. is wetland region containing large depressions which contain water for most of the year. The southeastern part contains coastal and hilly physiography.
This study is based on secondary data. Monthly district level data on ground water depth at 271 wells 2012, located within the respected districts of North-Eastern and South Eastern Part of Bangladesh, were collected from Bangladesh Water Development Board (BWDB) to analysis the groundwater depth of the study area. Then the monthly data were classified into three different seasons to find out the seasonal variation of groundwater depth of study area.

- $\quad$ Dry Season- October to February

- Pre-Monsoon- March, April and May

- Monsoon- June to September

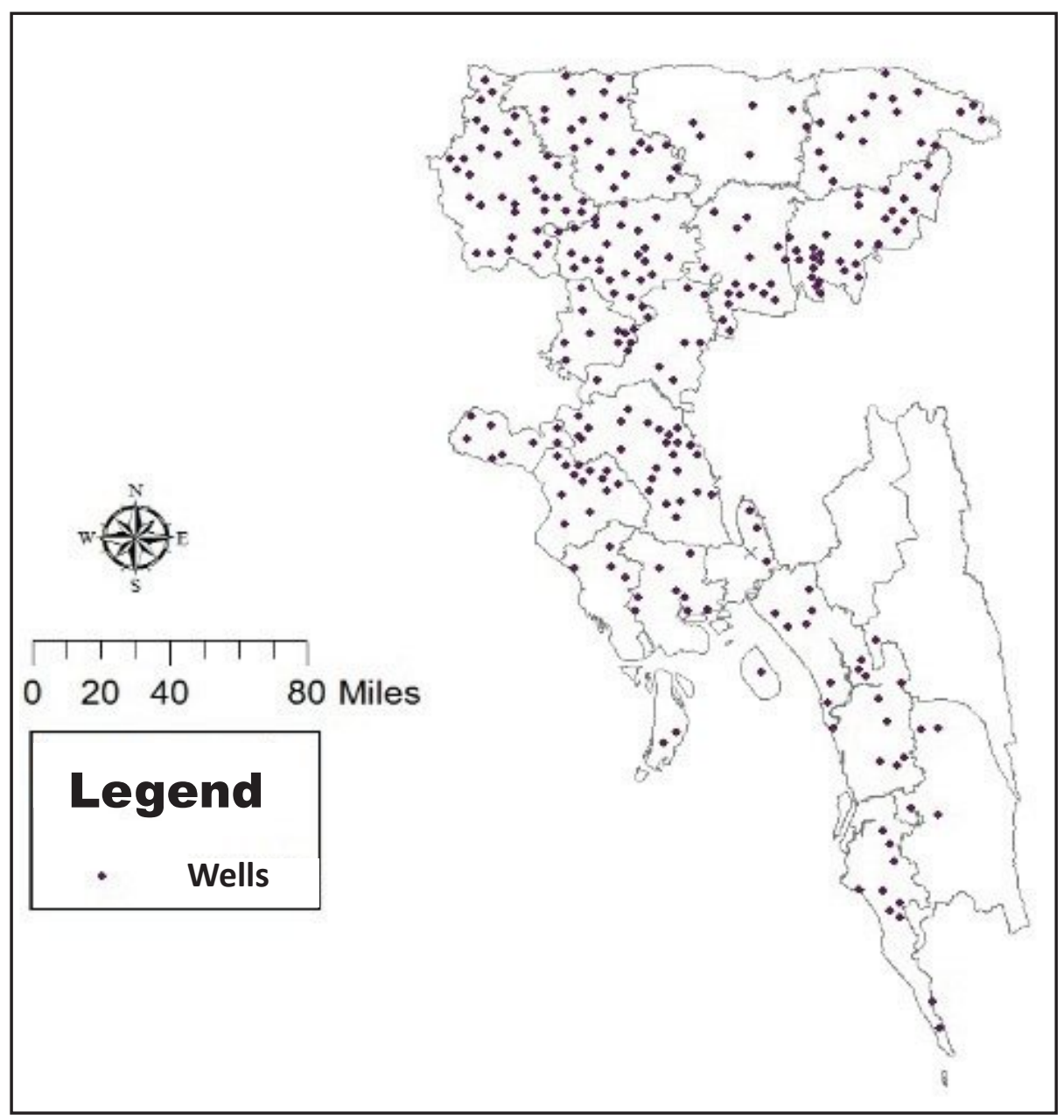

Fig. 2: Location of wells in study area.

The average groundwater depth at each well was calculated for each of the above mentioned seasons. From data manipulation to presentation ArcGIS 10.1 software was used. The wells were added to the study area map as point features. The attribute table contains the average ground water depth value for each of the well in each season. These values were interpolated using IDW (Inverse Distance Weighted) method. And then contour lines, at $3 \mathrm{~m}$ interval, were drawn to show groundwater depth variation across the study area. Then groundwater depth variability of 20 districts of North-Eastern and South Eastern Part of Bangladesh has been analyzed through Microsoft Excel.

\section{RESULTS AND DISCUSSIONS}

Groundwater aquifers in different parts of Bangladesh analyzed from groundwater data of BWDB till 1999 shows that, North-Eastern and South Eastern parts have groundwater in less depth than Western parts of Bangladesh (DPHE- BGS 1999). Groundwater recharge of Bangladesh from 1954 to 1988 stated that groundwater recharge is more in the Eastern parts of Bangladesh and minimum in the Western parts (DPHE-BGS 2001). 


\section{i) Dry Season Scenario}

Figure 3 distinctively portrays a comparative scenario of groundwater level in the Northeastern and Southeastern part of Bangladesh. This portion of the country comprises of several districts of Chittagong and Sylhet divisions. In dry season groundwater level ranges in between 2 to $12 \mathrm{~m}$ within this area.

In the Northeastern portion of the country groundwater level prevails in between 4 to $12 \mathrm{~m}$. Sylhet district has some specific sites where the ground water level is 12 meters or more and these specified locations are more urbanized than the rest of the Northeastern portion.

On the other hand, in the Southeastern portion of Bangladesh, groundwater level ranges in between 2 to 8 meters while a massive portion of this zone is dominated by a groundwater level of $4 \mathrm{~m}$. In the absolute hilly areas the water level is $2 \mathrm{~m}$, whereas in the comparatively populated urbanized area the water level prevails in between 6 to $8 \mathrm{~m}$.

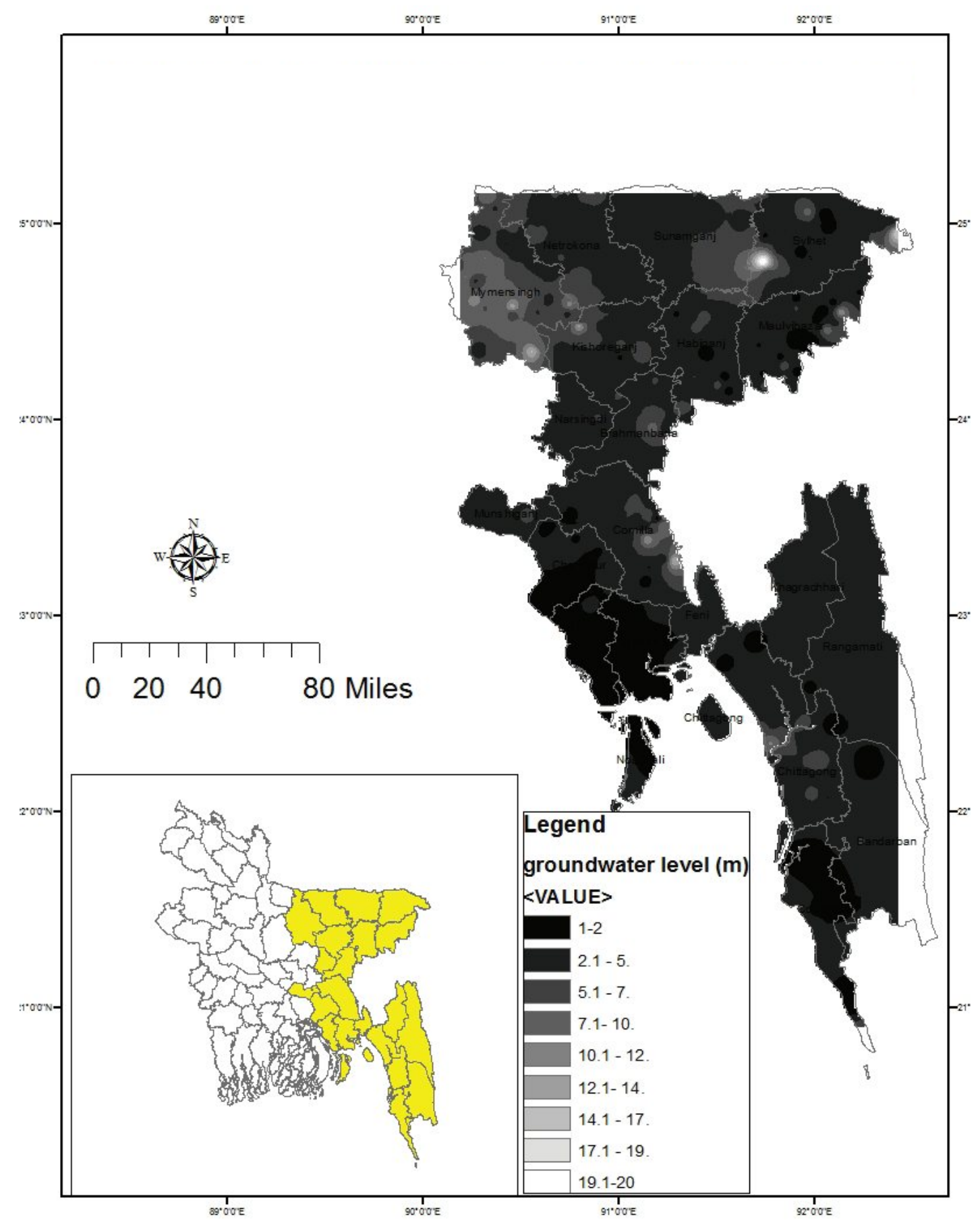

Fig. 3: Groundwater depletion seasonally in north-eastern and south eastern parts in Bangladesh 2012. 
However, owing to the low level of urbanization and prevalence of scattered settlement groundwater depletion is minor within this part of the country. At the same time people usually prefer surface water to be used vigorously for their daily usages and the opportunity of the groundwater to be replenished is more due to less development of urban structures within this arena. As a result the dry season scenario of groundwater depletion in this part of Bangladesh does not mark worthy and discernible.

\section{ii) Pre-monsoon Scenario}

Figure 3 illustrates groundwater depth variation across the study area during the pre-monsoon period. It shows that the groundwater depth ranges between 2 and $14 \mathrm{~m}$ during this season.

In the Sylhet division groundwater depth remains between 2 and $12 \mathrm{~m}$. Whereas in the Chittagong hill tracts the groundwater depth varies from 2 to $6 \mathrm{~m}$ only. Higher number of population and subsequently greater urbanization might be the reasons behind such variations.

Groundwater depth is also much lower in around Comilla district, ranging between 8 and $12 \mathrm{~m}$. Furthermore, the groundwater depletion is highest in Mymensingh and Kishoreganj district during this season. At certain well location, groundwater is found as low as $14 \mathrm{~m}$ in this area. Groundwater depletion scenario in dry and pre-monsoon season is almost quite similar.

\section{iii) Monsoon Scenario}

Figure 3, illustrates the situation of groundwater in the rainy season. The North-eastern part shows a peculiar situation. In the, central part of Sylhet city, there is closely spaced contour lines showing the wide disparity of groundwater level. The contour line ranges from 1 to $10 \mathrm{~m}$. The Southeastern parts show widely spaced contours (ranging from 2-8 $\mathrm{m}$ ) representing low variation in the ground water depth. Comilla shows some closely spaced contours, ranging from $2-6$ representing the urban development of Comilla city.

In 2010 groundwater depth increased in 35769 square kilometer area, which were 41958 square kilometer area and where groundwater depth were less than $5.3 \mathrm{~m}$. In the NorthEastern and Eastern part district, especially in Netrokona groundwater depth went to $20 \mathrm{~m}$ from $15 \mathrm{~m}$, In Munshiganj, Habiganj and Kishoreganj district groundwater level also decreased from less than $5 \mathrm{~m}$ to more than 7 meters in 2010 . Groundwater level in Chittagong and Feni also decreased to 7 $\mathrm{m}$ from $5 \mathrm{~m}$ in 2010 (Alam 2012) and these groundwater level is also decreasing in 2012.

\section{Variability Analysis}

The graph displays that most of the districts encounter a groundwater level, which falls in between 4 to $8 \mathrm{~m}$ during the dry season. However Netrokona district, among all others exhibits the highest level of diminution of groundwater level and the maximum deviation from the groundwater of 2004 in that area (Fig. 4).

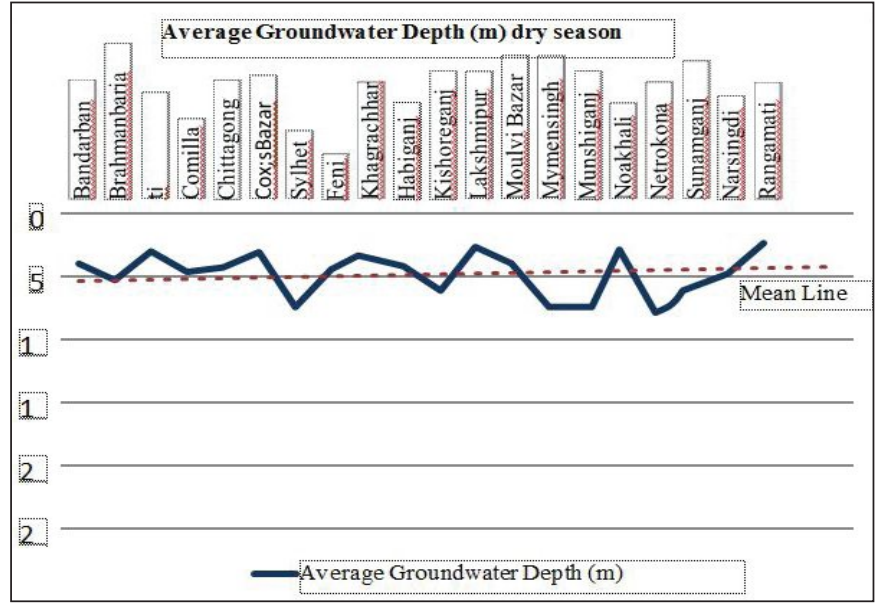

(a)

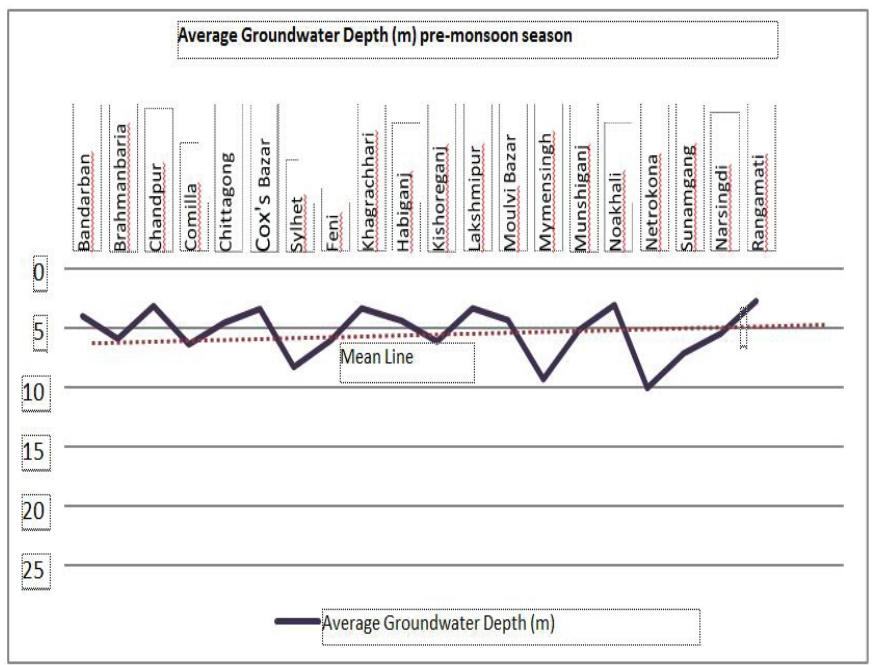

(b)

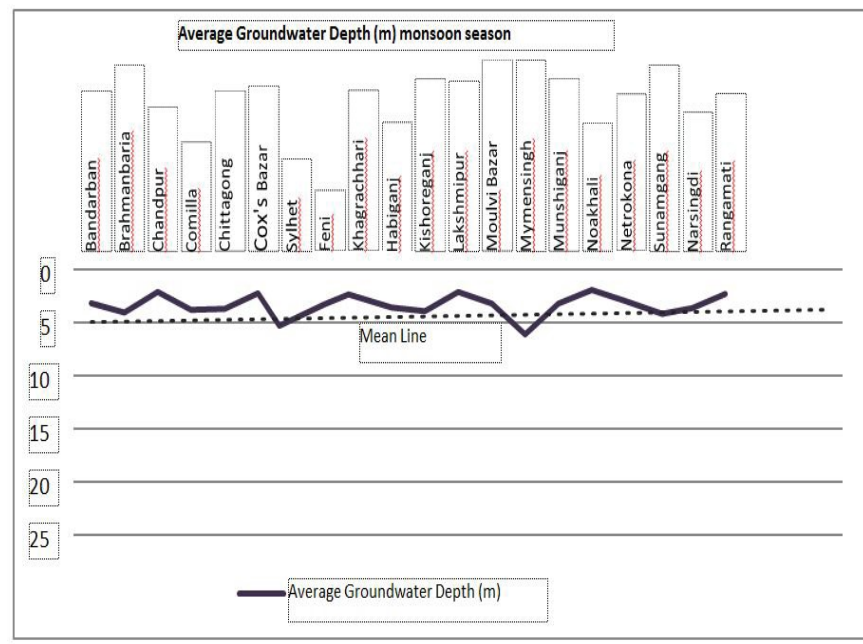

(c)

Fig. 4 (a, b, c): Variability analysis of average groundwater depth 2012 of north-eastern and south eastern part of Bangladesh. 
During the pre-monsoon period the overall groundwater level lies in between 3 to $10 \mathrm{~m}$ approximately except in the Netrokona district. It has been illustrated an extraordinary level of groundwater depletion in Netrokona district, which is eccentric from all other districts and its deviation from other district is maximized. However Habiganj, Kishoreganj and Sunamganj also exhibit a quite high level of drop down of groundwater than other districts which are approximately 10 $\mathrm{m}$ and $8 \mathrm{~m}$, respectively.

The monsoon period is characterized by enormous precipitation, which boosts up the recharge facility of groundwater and supposed to revive the groundwater level. The depletion of groundwater level in Netrokona district is highest as usual and in other districts it falls in between 3 to $8 \mathrm{~m}$ on an average approximately. However, in Sunamganj, Kishoreganj and Munshiganj besides of Netrokona this diminish is quite higher than other districts which is evidenced from the other districts groundwater level in 2004. These two districts along with Netrokona district portray huge deviation from the mean line of groundwater level (5 meter) of North-Eastern and Southeastern part of Bangladesh.

\section{CONCLUSIONS}

From this study significant variation of groundwater depth has been observed throughout the study area. In the Netrokona district of Bangladesh, the groundwater situation has been found to be worst. Other North-eastern part also shows the deteriorating groundwater condition. Conversely, southeastern part has relatively a good water level condition which indicates a huge spatial disparity of groundwater level throughout the country. We must keep in mind that ground water plays a very significant role to meet up the need of daily water demand of the residents live in cities in developing countries like Bangladesh. In most parts of the developing world rapid expansion in ground water exploitation occurred between 1970 and 1990 (UN/WWAP 2003, Villholth 2006). The overwhelming demand owing to increasing population principally stimulates the rising depletion rate. And if this falling trend of groundwater level continues, then it may invite land subsidence, groundwater pollution and other environmental hazards. So, the groundwater aquifer of our study area requires sustainable management to assure that this resource can continue to meet up the quantitative demands that substantially rest on it.

Bangladesh is located in a zone of ample annual effective precipitation and also it has proximity to the major river systems. But still it is not capable of utilizing its opportunities due to lack of proper management and effective implementation of the knowledge concerning the groundwater situation of Bangladesh. In order to revive its jeopardized groundwater condition, knowledge based management measures should be initiated.

\section{ACKNOWLEDGEMENTS}

Groundwater wells data of North-Eastern and South eastern parts of Bangladesh collected from Bangladesh water Development Board (BWDB) and analysis of data were carried out in the Geographic Information Lab of the Department of Geography and Environment with the help of Dr. Towhida Rashid. Bangladesh water Development Board (BWDB) and Dr. Towhida Rashid Associate Professor, Department of Geography and Environment are gratefully acknowledged for their generous help and supports to combine all data.

\section{REFERENCES}

Alam, M. E., 2011, The Updated Groundwater Zoning Map of Bangladesh.

Alam, S., 2012, Country Experience: Bangladesh POPULATION AND HOUSING CENSUS 2011.

Anon, 2002, Government of the People's Republic of Bangladesh Ministry of Local Government, Rural Development and Co-operatives, Local Government Division.

Ali., A. M. 2011, Fundamentals of Irrigation and On-farm Water Management. Springer-Verlag New York Inc. New York. v. 1., p. 18.

BADC (Bangladesh Agricultural Development Corporation)., 2010, Minor Irrigation Survey Report 2009-10. BADC, Dhaka, p. 3.

BBS, 2012, Population and Housing Census 2011, Bangladesh at a glance. In Population and Housing Census 2011. Bangladesh Bureau of Statistics (BBS), Statistics and Informatics Division, Ministry of Planning, Bangladesh. Availableat:http://www.bbs.gov.bd/WebTestApplication/ userfiles/Image/Census2011/Bangladesh_g.

DPHE-BGS, 2001, Arsenic Contamination of Groundwater in Bangladesh, British Geological Survey (BGS) and Department of Public Health Engineering (DPHE) Govt. of Bangladesh; rapid investigation phase, Final Report.

DPHE-BGS-MML, 1999, Groundwater Studies for Arsenic Contamination in Bangladesh. Phase-I: Rapid. Investigation Phase. Six Volumes. British Geological Survey and Mott MacDonald Ltd. (UK).

Akther, H., Ahmed., M. S. and Rashed, K. B. S., 2009, Spatial and Temporal Analysis of Groundwater Level Fluctuation in Dhaka City, Bangladesh. Asian Journal of Earth Science. v. 2(2), pp. 49-57.

Nwankwoala, H. O., 2011, An integrated approach to sustainable groundwater development and management in Nigeria. Journal of Geology and Mining Research. v. 3(5), pp. 123-130.

Hoque, M. A., Hoque, M. M. and Ahmed, K. M., 2007, Declining groundwater level and aquifer dewatering in Dhaka metropolitan area, Bangladesh: Causes and quantification. Hydrogeol. Jour., v. 15(8), pp.1523-1534.

Klump, S., Kipfer. R., Cirpka, O. A., Harvey, C. F., Brennwald, M. S., Ashfaque, K. N., Badruzzaman, A. B. M., Hug, S. J. and Imboden, D. M., 2006, Groundwater dynamics and arsenic mobilization in Bangladesh assessed using noble gases and tritium. Environ. Sci. Tech., v. 40, pp. 243-250. 
Menon, S., 1998, Groundwater management: need for sustainable approach. Proceedings of the seminar on Artificial Recharge of Groundwater. Central Groundwater Board, Ministry of Water Resources, New Delhi. December.www.wikipedia.org.

Oteze, G. E., 2006, Management approaches for Nigeria's water resources. Jour. Min. Geol. v. 42(1), pp. 15-20.

Oyebande, L., 2004, Power generation and development in the Nigeria's power sector. Int. Jour. Hydropower Dams, v. 6, pp. 213-219.

Rahman, Md. M. and Mahbub, A. Q. M., 2012, Groundwater Depletion with Expansion of Irrigation in Barind Tract: A Case Study of Tanore Upazila. Jour. of Water Resource and Protection, v. 4(8), pp. 567-575.

Rashid, H., 1991, Geography of Bangladesh. The University Press Limited, Dhaka, Bangladesh.

Rasid, H. and Pramanik, M. A. H., 1990, Visual Interpretation of Satellite Imagery for Monitoring Floods in Bangladesh. Springer-Verlag New York Inc., U.S.A.

Shah, T., 1993, Groundwater markets and irrigation development: political economy and practical policy. Oxford University Press, Bombay.

Shamsudduha, M., Chandler, R. E., Taylor. R. G. and Ahmed,
K. M., 2009, Recent trends in groundwater levels in a highly seasonal hydrological system: the GangesBrahmaputra-Meghna Delta. Hydrol. Earth Syst. Sci., v. 13, pp. 2373-2385.

UNEP (United Nation Environment Program), 2003, Groundwater and its susceptibility to degradation: A global assessment of the problem and options for management. Kenya, Nairobi.

UN/WWAP (United Nations/ World Water Assessment Programme), 2003, UN World Water Development Report: Water for people, water for life. UNESCO (United Nations Educational, Scientific and Cultural Organization) and Berghahn Books, Paris, New York and Oxford.

Villholth, K. G., 2006, Groundwater assessment and management: Implications and opportunities of globalization. Hydrogeol. Jour., v. 14, pp. 330-339.

Zahid, A. and Uddin, A. S. R., 2013, Groundwater Resources Development in Bangladesh: Contribution to Irrigation for Food Security and Constraints to Sustainability. 